\title{
Relator Terms for Rare Book, Manuscript, and Special Collections Cataloging
}

\author{
(SECOND Edition)
}

\section{ACRL RBMS Standards Committee}

\section{Introduction}

The following list of relator terms has been approved for use in rare materials cataloging by the Standards Committee of the Rare Books and Manuscripts Section of the Association of College and Research Libraries. It is now published in this second edition.

The present list is a further revision of one originally proposed by the Ad Hoc Committee of the Independent Research Libraries Association in Proposals for Establishing Standards for the Cataloguing of Rare Books and Specialized Research Materials in Machine-Readable Form (Worcester, Mass., 1979), and published in its first edition in CひRL News, September 1980. Comments from the Library of Congress and from members of the rare books and special collections community have been taken into account in preparing this second edition.

The list, in its first edition, was transmitted to the ALA Resources and Technical Services Division Committee on Cataloging: Description and Access, with the request that the second edition of the Anglo-American Cataloguing Rules, rule $21.0 \mathrm{D}$, be amended to allow for the optional use of these terms. It is anticipated that the list will be forwarded to the Library of Congress and the Federal Library Committee to have "relator codes" assigned, according to the technique for content designating specialized added entries accepted by LC and ALA in 1979. The Library of Congress also has indicated that consideration is being given to modifying the ABACUS decision relative to rule $21.0 \mathrm{D}$ so far as rare book relators are concerned.

It is the recommendation of the RBMS Standards Committee and the IRLA Ad Hoc Committee that this standard list be adopted by all rare books and specialized collections, especially those who participate in a bibliographic network.

\section{Purpose of the list}

The need for rare book and special collections library users to be able to distinguish added entries for different kinds of contributors to the intellectual content, physical production or provenance of items in their collections has long been recognized by rare books librarians. Relator terms are used in manual cataloging systems to create discrete special files for access by the names of illustrators, printers, former owners, etc., or to ar- range bibliographic records within a single catalog file in an order reflecting these distinctions.

The IRLA Ad Hoc Committee studied the use of relator terms in MARC cataloging and found that they would be essential if special files were to be created in an automated system. In addition, the use of relators would potentially provide libraries with the capability of conducting specialized searches on-line in their data bases, and of producing valuable output lists, inventories, etc. However, to derive these benefits in a network environment, relator terms and the manner of their use in the bibliographic record needed to be standardized to the greatest degree possible.

\section{Nature and scope of the list}

This list does not attempt to be exhaustive in enumerating all possible functions a person or body may perform in the production or history of a bibliographic item. Most of the relator terms already provided in the second edition of the Anglo-American Cataloguing Rules have not been included; however, it is recognized that certain types of specialized collections (e.g., legal materials) may wish to use the relators contained therein for producing specialized lists or arrangements of entries. The present list, rather, attempts to give those functions that are considered to correspond to widely accepted types of associations with printed or manuscript materials. Brief definitions or use notes are provided where necessary to avoid ambiguity.

A reference structure between various terms has been provided. This follows the format recommended in American National Standards Institute, American National Standard Guidelines for Thesaurus Structure, Construction, and Use (New York, 1973), as illustrated in the following table:

$\begin{array}{ll}\text { Cross-references } & \text { Symbols } \\ \text { Broader term } & \text { BT } \\ \text { Narrower term } & \text { NT } \\ \text { Related term } & \text { RT } \\ \text { Use } & \text { Use } \\ \text { Used for } & \text { UF }\end{array}$

Terms authorized for use are given in capital letters; unauthorized synonymous terms appear in lower case letters.

Some of these relator terms pertain largely or exclusively to "copy-specific" added entries (e.g., FORMER OWNER, HONOREE). Catalogers should be careful to preserve this important dis- 
tinction in the MARC record, using the mechanisms for copy-specific added entries provided by their network or bibliographic utility, and providing in the bibliographic description appropriate copy-specific notes.

\section{MARC application}

Relators should be entered in the subfield $\neq \mathrm{e}$ in added entry fields $700 / 710$ as appropriate. If a person or body is associated with more than one function, do not repeat the subfield $\neq e$; rather, repeat the added entry field as many times as there are functions to be indicated, using an appropriate relator in each case. Alternately, libraries interfiling various types of relator entries in a single alphabetic sequence may wish only to employ the broader relator terms such as BOOK DESIGNER in an inclusive manner rather than using all the specific narrower terms such as TYPE DESIGNER or TYPOGRAPHER (etc.) when such usage would result in multiple entries for the same person or body working in various capacities on the same book. Libraries with extensive holdings of a single person or firm may wish to employ all the most specific terms in elaborately subdivided files. Each library should apply the relator terms in the manner most appropriate to its own needs, while working within this framework of standardized forms to provide the benefit of network interaction.

\section{Maintenance of the list}

The list of relator terms will be maintained by the editor of the Relator List on behalf of the RBMS Standards Committee. Updates to the list will appear occasionally, published in the library press. Upon the advice of the Standards Committee, the editor shall prepare a new edition for publication. Additional terms for the list should be submitted in writing and:

1) indicate the scope or use of each term;

2) indicate reason for need of the term;

3) provide an appropriate reference structure. Queries and comments may be addressed to: Chair, Standards Committee, Rare Books and Manuscripts Section, ACRL/ALA, 50 E. Huron Street, Chicago, IL 60611, Attention: Relator List.

\section{Relator List}

\section{ANNOTATOR}

Use for writer of manuscript annotations in a printed book.

BT ASSOCIATED NAME

\section{ASSIGNEE}

Use for person or organization to which a license for printing or publishing has been transferred.

RT LICENSEE

\section{ASSOCIATED NAME}

Use as a general relator for a name associated with or found in a book, or which cannot be determined to be that of a FORMER OWNER or other designated relator indicative of provenance.

NT ANNOTATOR

DONOR

FORMER OWNER

HONOREE

INSCRIBER

SIGNER

\section{BINDER}

RT BINDING DESIGNER

BINDING DESIGNER

RT BINDER

BOOK DESIGNER

UF Designer of binding

\section{BOOK DESIGNER}

Use for person or firm responsible for the entire graphic design of a book, including arrangement of type and illustration, choice of materials, and processes to be used.

NT TYPE DESIGNER

TYPOGRAPHER

RT BINDING DESIGNER

BOOKJACKET DESIGNER

GRAPHIC TECHNICIAN

ILL. [USTRATOR]

UF Designer of book

BOOKJACKET DESIGNER

RT BOOK DESIGNER

UF Designer of bookjacket

BOOKPLATE DESIGNER

UF Designer of bookplate

BOOKSELLER

RT DISTRIBUTOR

PUBLISHER

Bowdlerizer Use CENSOR

CALLIGRAPHER

CARTOGRAPHER

CENSOR

Use for censor, bowdlerizer, expurgator, etc., official or private.

UF Bowdlerizer

Expurgator

COMPOSITOR

UF Typesetter

\section{COPYRIGHT HOLDER}

CORRECTOR

Use for scriptorium official who corrected the work of a scribe; for printed matter use PROOFREADER.

Counterfeiter Use FORGER

DEDICATEE

Use for person or organization to whom a book or manuscript is dedicated (not the recipient of a gift).

\section{RT DEDICATOR}

\section{DEDICATOR}

Use for the author of a dedication. The dedication may be a formal statement or it may be in epistolary or verse form.

RT DEDICATEE

Designer of binding Use BINDING DESIGNER 
Designer of book Use BOOK DESIGNER

Designer of bookjacket Use BOOKJACKET DESIGNER

Designer of bookplate Use BOOKPLATE DESIGNER

Designer of type Use TYPE DESIGNER

DISTRIBUTOR

RT BOOKSELLER

PRINTER

PUBLISHER

SPONSOR

\section{DONOR}

Use for donor of book to present owner; donor to previous owner is designated as FORMER OWNER.

BT ASSOCIATED NAME

RT HONOREE

ENGRAVER

BT GRAPHIC TECHNICLAN

NT METAL-ENGRAVER

WOOD-ENGRAVER

\section{ETCHER}

BT GRAPHIC TECHNICIAN

Expurgator Use CENSOR

FORGER

UF Counterfeiter

FORMER OWNER

Use for person or organization owning book at any time in the past. Include person or organization to whom book was once presented as named in a statement inscribed by another person or organization; person or body giving book to present owner is designated as DONOR.

\section{BT ASSOCIATED NAME \\ RT INSCRIBER \\ SIGNER}

\section{GRAPHIC TECHNICLAN}

Use as a general relator for person responsible for the realization of a design in a medium from which a print may be produced. If person who conceives the design (i.e., ILL. [USTRATOR]) also realizes it, added entries for both functions may be used as needed. Special print collections and some libraries may prefer relators designating specific processes. If no appropriate term is found in this list, a specific relator may be supplied, and submitted for possible addition to the list (see Introduction).

NT ENGRAVER

ETCHER

LITHOGRAPHER

METAL-ENGRAVER

WOOD-ENGRAVER

RT BOOK DESIGNER

ILLUMINATOR

ILL.[USTRATOR]

PRINTER OF PLATES

\section{HONOREE}

Use for person in memory or honor of whom a book is donated.

BT ASSOCIATED NAME
RT DONOR

UF Memorial

ILLUMINATOR

RT GRAPHIC TECHNICIAN

ILL. [USTRATOR]

RUBRICATOR

ILL. [USTRATOR]

AACR2 form ill. required.

Use for person who conceives a design or illustration.

RT BOOK DESIGNER

GRAPHIC TECHNICIAN

ILLUMINATOR

LITHOGRAPHER

PHOTOGRAPHER

RUBRICATOR

Imprimatur Use LICENSOR

INSCRIBER

Use for person who signs a presentation statement.

BT ASSOCIATED NAME

RT FORMER OWNER SIGNER

LICENSEE

Use for original recipient of right to print or publish.

RT ASSIGNEE

LICENSOR

Use for signer of license, imprimatur, etc.

UF Imprimatur

\section{LITHOGRAPHER}

Use for person who prepares stone or grained plate for lithographic printing, including graphic artist creating original design while working directly on surface from which printing will be done.

BT GRAPHIC TECHNICIAN

RT ILL. [USTRATOR]

Memorial Use HONOREE

METAL-ENGRAVER

BT ENGRAVER

GRAPHIC TECHNICIAN

PAPERMAKER

PHOTOGRAPHER

Use for person responsible for taking photographs used to illustrate a book either in their original form or as reproductions.

RT ILL. [USTRATOR]

Plates, Printer of Use PRINTER OF PLATES

PRINTER

Use for printer of texts, whether from type or plates (e.g., stereotype)

RT DISTRIBUTOR

PRINTER OF PLATES

TYPOGRAPHER

PRINTER OF PLATES

Use for printer of illustrations or designs from plates.

RT GRAPHIC TECHNICIAN PRINTER

UF Plates, Printer of

PROOFREADER 
Use for corrector of printed matter only; for manuscripts use CORRECTOR.

\section{PUBLISHER \\ RT BOOKSELLER \\ DISTRIBUTOR}

\section{RECIPIENT}

Use for person to whom letters are addressed.

RUBRICATOR

RT ILLUMINATOR

ILL. [USTRATOR]

\section{SCRIBE}

Use for maker of pen-facsimiles of printed matter as well as for amanuensis and for writer of manuscripts proper.

\section{SIGNER}

Use for signature which appears in a book without a presentation or other statement indicative of provenance.

\section{BT ASSOCIATED NAME}

RT FORMER OWNER INSCRIBE R

\section{SPONSOR}

Use for person or body which sponsors the production of book, e.g., the entity "under the auspices of" which book has been written, printed, published, etc.

RT DISTRIBUTOR

TYPE DESIGNER

Use for person who designed the type face used in a particular book.

BT BOOK DESIGNER

RT TYPOGRAPHER

UF Designer of type

Typesetter Use COMPOSITOR

TYPOGRAPHER

Use for person primarily responsible for choice and arrangement of type used in a book. If person who selects and arranges type is also responsible for other aspects of the graphic design of a book (i.e., BOOK DESIGNER), added entries for both functions may be used as needed.

BT BOOK DESIGNER

RT PRINTER

TYPE DESIGNER

WOOD-ENGRAVER

BT ENGRAVER

GRAPHIC TECHNICIAN

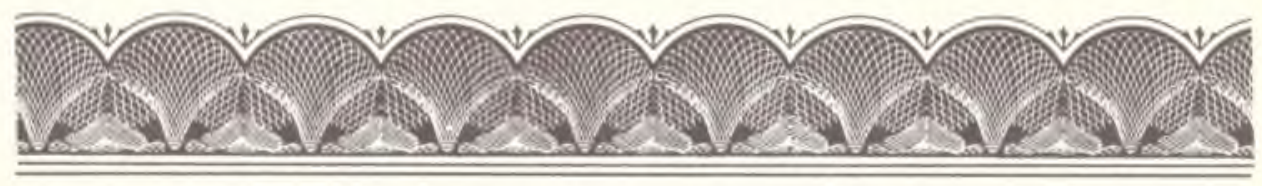

\section{ACRL'S FAST JOB LISTING}

Looking for a job? Our Fast Job Listing will send you job postings received at ACRL headquarters four weeks before they appear in C¿RL. News. The Fast Job Listing Service also contains advertisements which, because of narrow application deadlines, will not appear in C\&RL News.

The ACRL office prepares a Fast Job Listing circular at the beginning of each month and mails it to subscribers first class. The circular contains all job announcements received during the previous four weeks.

The cost of a six-month subscription is $\$ 10$ for ACRL members and \$15 for nonmembers. You may enter your subscription below.

Please enter my subscription to the ACRL Fast Job Listing Service.

I am a member of ACRL and am enclosing \$I0.

I am not a member of ACRL and am enclosing \$15.

NAME:

\section{ADDRESS:}

Please make checks payable to ACRL/ALA and send to Fast Job Listing Service, ACRL/ALA, 50 E. Huron St. Chicago, IL 60611.

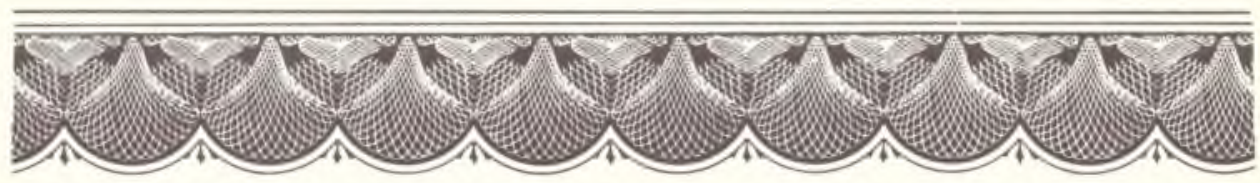

